\title{
Biochar Capacity to Mitigate Acidity and Adsorb Metals-Laboratory Tests for Acid Sulfate Soil Drainage Water
}

\author{
Niko Kinnunen • Annamari (Ari) Laurén • \\ Jukka Pumpanen · Tiina M. Nieminen • \\ Marjo Palviainen
}

Received: 21 May 2021 / Accepted: 21 October 2021 / Published online: 3 November 2021

(C) The Author(s) 2021, corrected publication 2022

\begin{abstract}
A 96-h laboratory experiment was conducted to assess the potential of biochar as a water protection tool for acid sulfate soil runoff. Acid sulfate soils pose a risk to water bodies due to acid, metal-rich runoff, especially in drained peatland forests. New water protection methods, such as adsorption with biochar, are needed. We investigated the capability of spruce and birch biochar to adsorb metals and reduce acidity in the water. Water from an acid sulfate site was stirred with biochar, biochar with lime, and biochar with ash. We determined water $\mathrm{Al}$, $\mathrm{S}, \mathrm{Fe}, \mathrm{Cu}, \mathrm{Co}, \mathrm{Cd}, \mathrm{Ni}$, and $\mathrm{Zn}$ concentrations periodically, as well as $\mathrm{pH}$ and total organic carbon at the beginning and the end of the experiment. The studied substances are considered the most abundant and environmentally harmful elements in the acid sulfate soils in Finland. Biochar surface characteristics were
\end{abstract}

N. Kinnunen $(\varangle) \cdot$ J. Pumpanen

University of Eastern Finland, Kuopio, Finland

e-mail: niko.kinnunen1@uef.fi

A. (. Laurén

School of Forest Sciences, Faculty of Science

and Forestry, University of Eastern Finland, Yliopistokatu

7, PO Box 111, 80101 Joensuu CampusJoensuu, Finland

T. M. Nieminen

Natural Resources Institute Finland (Luke),

Latokartanonkaari 9, 00790 Helsinki, Finland

M. Palviainen

Department of Forest Sciences, University of Helsinki,

PO-Box 27, 00014 Helsinki, Finland analyzed with FTIR spectroscopy. Concentration changes were used to parametrize adsorption kinetics models. Biochar adsorbed metals and increased $\mathrm{pH}$, but lime and ash additives did not always improve the adsorption. Spruce biochar and ash addition had generally higher adsorption than birch biochar and lime addition. The adsorption was dominated by $\mathrm{Al}$ and $\mathrm{Fe}$ at lower $\mathrm{pH}$, while increasing $\mathrm{pH}$ improved the adsorption of $\mathrm{Cd}$ and $\mathrm{Zn}$. The results show that biochar can increase the water $\mathrm{pH}$, as well as adsorb $\mathrm{Al}$, $\mathrm{Fe}, \mathrm{Co}, \mathrm{Cd}, \mathrm{Ni}$, and $\mathrm{Zn}$. Further work could include an actual-scale biochar reactor in a laboratory and field conditions.

Keywords Biochar - Acidity - Adsorption - Metal · Water quality

\section{Introduction}

Acid sulfate soils cover approximately 17 million hectares globally (Andriesse \& van Mensvoort, 2002). The largest deposits of acidic sulfate soils in Europe are found in Finland (Roos \& Åström, 2005, Fältmarsch et al., 2007). They were mostly formed around 7500-400 years ago in the coastal regions of the Littorina Sea or Baltic Sea. There, microbial processes resulted in the formation of poorly soluble iron sulfide sediments, rich in other metals as well, including potentially toxic heavy metals (Sutela et al., 2012). Currently, these areas are located at 
the southern and western coast of Finland, harmless when buried in the anoxic soil layers. However, disruptive soil management, such as draining peatlands for forestry and agriculture, and seasonal variation in the water table expose these layers to oxic conditions. Peatlands cover almost one-third of Finland's land area, and 53\% of them have been drained for forestry at the whole country level, and as much as $75 \%$ in southern Finland (Sallinen et al., 2019). Drained peatland forests represent approximately $25 \%$ of the total forest land area in Finland (Nieminen et al., 2018); thus, the open ditches contribute greatly to the exposure of sulfidic layers beneath the peat (Saarinen et al., 2013; Sikström \& Hökkä, 2016).

When sulfidic soil layers are exposed to aerobic conditions, sulfides are oxidized, which leads to the formation of sulfuric acid and thus severe acidification ( $\mathrm{pH} 2.5-4.5)$ of the soil (Fältmarsch et al., 2007, Nordmyr et al., 2008). Acidity increases the mobility and leaching of metals from the soil minerals (Saarinen et al., 2013). Consequent acidification of the drainage recipient water poses a severe risk to aquatic biota. The $\mathrm{pH}$ value 5.5 is generally considered as a critical threshold level, since most aquatic organisms cannot survive in $\mathrm{pH}$ conditions below that level (Palko, 1994; Vuori et al., 2009). This has caused large-scale adverse effects on rivers of the western Finland for decades, and resulted in occasional mass fish deaths and in worst cases permanent damage to fish populations, water quality, and aquatic ecosystems (Roos \& Åström, 2005, Fältmarsch et al., 2007, Nordmyr et al., 2008, Sutela et al., 2012). The metal export from the acid sulfate soils to watercourses is multiple times larger than that of the entire industry in Finland, and it is estimated to increase due to climate change (Roos \& Åström, 2005; Sutela et al., 2012). These problems call for a new, environmentally, and economically sustainable way of mitigating acidity and metal export. Common methods used to treat metal-polluted water generally require centralized facilities and trained people, as well as use various chemicals and generate waste (Abdullah et.al, 2019, GarciaChevesich et al, 2020). A potential solution could be water purification via adsorption using biochar-filled reactors in ditch drains.

Biochar is promising but little-studied, method to reduce the adverse waterborne effects caused by acid sulfate soils (Dang et al., 2015). It is formed as a side product of pyrolysis in which organic material, such as woodchip, straw, or manure, is heated under low oxygen supply. The main products of the process are heat, biogas, and biooil. Biochar is characterized by especially high specific surface area and cation exchange capacity, as well as a highly porous structure, making it an efficient adsorbent to a variety of compounds (Saarela et al., 2020). Biochar has similar properties to activated carbon but is much cheaper and easier to produce (Thompson et al., 2016; Li et al., 2017). It is generally slightly weaker adsorbent but can in some cases achieve similar or even better results, varying with the metal adsorbed, $\mathrm{pH}$ of the solution, and the type of feedstock used to create the biochar (Inyang et al., 2012; Li et al., 2017). For example, Li et al. (2017) reported sorption capacities of two different biochars for the removal of $\mathrm{Cd}$ (dairy manure produced at 200 and $350{ }^{\circ} \mathrm{C}$ and oak bark at $400-450{ }^{\circ} \mathrm{C}$ ). Manure biochar had an adsorption capacity of 31.9 and $51.4 \mathrm{mg} \mathrm{g}^{-1}$, while the oak biochar had an adsorption capacity of $5.40 \mathrm{mg} \mathrm{g}^{-1}$. Chen et al. (2011) tested the capacity of hardwood (produced at $450{ }^{\circ} \mathrm{C}$ ) and corn straw biochar (produced at $600{ }^{\circ} \mathrm{C}$ ) to adsorb $\mathrm{Zn}$ and $\mathrm{Cu}$. Both metals showed significantly stronger adsorption into the corn straw biochar (6.79 to $12.5 \mathrm{mg} \mathrm{g}^{-1}$ for $\mathrm{Cu}$ and 4.54 to $11.0 \mathrm{mg} \mathrm{g}^{-1}$ for $\mathrm{Zn})$. These results show that biochar adsorption capacity depends on multiple factors related both to biochar quality and the solution properties, and therefore its use as an adsorbent needs careful planning (Chen et al., 2011) It has been shown that biochar can adsorb nutrients and heavy metals from water as well as increase its $\mathrm{pH}$ (Lafdani et al., 2020; Saarela et al., 2020), but it has not been yet tested as a water protection tool at acidic sulfate sites, where especially low $\mathrm{pH}$ alters metal availability and weakens the adsorption of anions and cations (Ahmadvand et al., 2018; Shin et al., 2018). Increasing water $\mathrm{pH}$ up to a certain point causes a negative net charge at the biochar surface, which allows it to bind positive metal cations such as $\mathrm{Cd}^{2+}$. Higher $\mathrm{pH}$ also reduces the competition with $\mathrm{H}^{+}$ions (Li et al., 2017, Senthilkumar \& Prasad, 2020).

The aim of this study was to assess the capacity of spruce and birch biochar to neutralize runoff water and adsorb iron, aluminum, and heavy 
metals $(\mathrm{Cd}, \mathrm{Zn}, \mathrm{Ni}, \mathrm{Co}, \mathrm{Cu})$ from water in drained peatlands located in areas with sulfide-bearing sediments. These selected metals are known to be harmful to water ecosystems and are abundant in the sulfate soils of Finland's west coast. Other possible candidates to monitor in this study were $\mathrm{Pb}$ and $\mathrm{As}$, but $\mathrm{Pb}$ concentrations in these sites have been found to be low, whereas As is mainly only present in southern Finland. We conducted a laboratory experiment, where runoff water from acid sulfate soil area was stirred with two different types of biochar (birch and spruce) as well as lime and ash as additives. Lime and ash were included to study how raising the water $\mathrm{pH}$ affects adsorption. Adsorption was estimated via decrease in metal concentration in water, after which adsorption kinetic models were fitted to the data. The main hypotheses were as follows: (1) Biochar can adsorb metals from water; (2) Adding lime and ash increases the adsorption; (3) Biochar neutralizes acid drainage water.

\section{Material and Methods}

Water for the experiment was collected from drained peatland with sulfide-bearing sediments. Kiimakorpi study area is located in Alaveteli $\left(63^{\circ} 43^{\prime} \mathrm{N}, 23^{\circ} 24^{\prime}\right.$ E) in western Finland (Fig. 1). The area is 100 ha and it has been drained for forestry in the late 1960s. The forest stand is dominated by Scots pine (Pinus sylvestris L.) with some mixture of downy birch (Betula pubescens Erhr.).

Water for the adsorption experiment was collected as a one-time grab sample from the main ditch draining Kiimakorpi in May 2020. According to the continuous water quality monitoring, $\mathrm{pH}$ in the runoff water varies between 4.0 and 5.5, and the minimum is usually in May (see https://ehp-data.com/ stations at stations KKY Kokkola1, -2 and -control). However, we did not hit the spring overflow peak, where metal concentrations are usually higher.

Water was used in a shaker test, used to observe concentration changes resulting from biochar
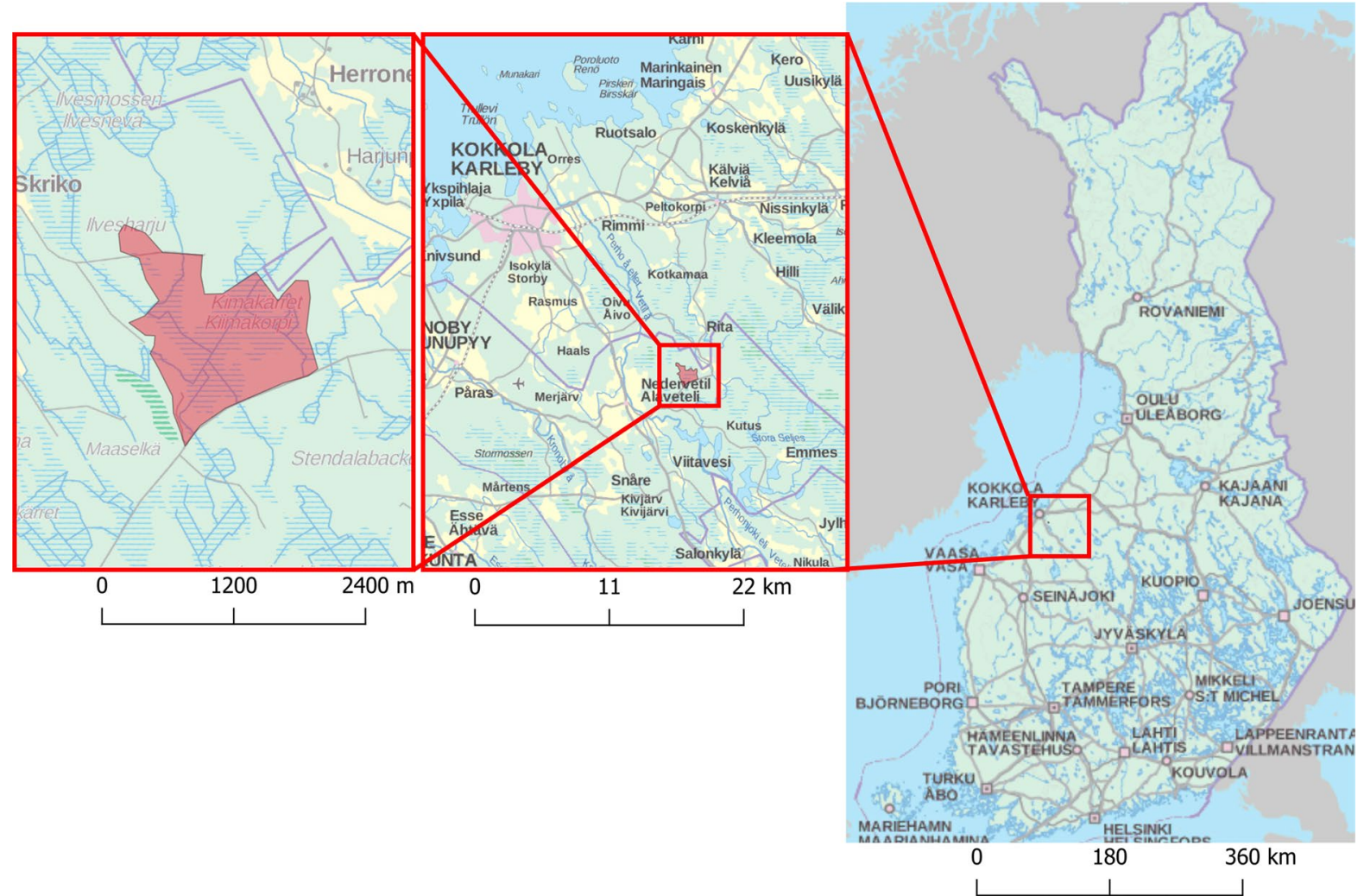

Fig. 1 Map of the Kiimakorpi site, located at the west coast of Finland near the city of Kokkola 
addition. The two commercial biochar types used in the experiment were Norway spruce (Picea abies Karst.) and silver birch (Betula pendula, Roth), produced by slow pyrolysis in $600{ }^{\circ} \mathrm{C}$ (Carbofex Ltd., Tampere, Finland). We also used two additives to increase water $\mathrm{pH}$, which were common gardening lime (Kekkilä garden) and commercial ash under product name T.U.H.K.A-Oulun Energia. The experiment was conducted at room temperature, since it is known that temperature can affect the adsorption parameters. Water was sampled into 1-L plastic jars, and $5 \mathrm{~g}$ of biochar, lime, and ash was added in refillable cotton tea bags, depending on the treatment according to Table 1. Biochar properties (see Saarela et al., 2020) are shown in Table 2.

Each treatment had 5 replicates, resulting in a total of 35 samples. A $20-\mathrm{mL}$ sample of water was collected from each jar at the beginning to

Table 1 Experimental setup. Total of seven different types of samples was prepared: Control sample with only water, birch biochar, birch biochar with lime, birch biochar with ash, spruce biochar, spruce biochar with lime, and spruce biochar with ash

\begin{tabular}{lllll}
\hline $\begin{array}{l}\text { Sample } \\
\text { code }\end{array}$ & Contents & \multicolumn{2}{c}{ Replicates } \\
\cline { 2 - 4 } & $\begin{array}{l}\text { Biochar } \\
(5 \mathrm{~g})\end{array}$ & $\begin{array}{l}\text { Additive } \\
(5 \mathrm{~g})\end{array}$ & Water $(\mathrm{L})$ \\
\hline Control & None & & 1 & 5 \\
Birch & Birch & None & 1 & 5 \\
Birch lime & Birch & Lime & 1 & 5 \\
Birch ash & Birch & Ash & 1 & 5 \\
Spruce & Spruce & None & 1 & 5 \\
Spruce lime & Spruce & Lime & 1 & 5 \\
Spruce ash & Spruce & Ash & 1 & 5 \\
\hline
\end{tabular}

Table 2 Properties of the biochars used. $\mathrm{pH}$ and electric conductivity were measured on a 1:2.5 v:v biochar/water solution with WTW pH 340 m (WTW GmbH, Weilheim, Germany). The specific surface area was measured using the N2 adsorp- determine the initial metal and $\mathrm{S}$ concentrations. We used a platform shaker (New Brunswick ${ }^{\mathrm{TM}}$ Innova ${ }^{\circledR}$ 2300, Eppendorf Nordic A/S, Denmark) to stir the water and thus increase the contact that biochar has with the metals and $\mathrm{S}$ in water. The experiment persisted for 5 days $(96 \mathrm{~h}$ ) at $105 \mathrm{rpm}$, and water samples of $20 \mathrm{~mL}$ were collected at time points 2, 4, 8, 22.5, 28, 46, 52, 76, and $96 \mathrm{~h}$ from the beginning of stirring. The samples were taken with $20-\mathrm{mL}$ plastic syringes and filtered with $0.45-\mu \mathrm{m}$ syringe filters. An ICP-OES analyzer was used to monitor $\mathrm{S}, \mathrm{Al}, \mathrm{Fe}, \mathrm{Cu}, \mathrm{Co}$, $\mathrm{Cd}, \mathrm{Ni}$, and $\mathrm{Zn}$ concentrations in the water samples. The method used followed the SFS-EN ISO 17294-2 standard for water quality analyses. Only $\mathrm{S}$ and the metals were included in the analysis for this study. The detection limit was $0.01 \mu \mathrm{g} \mathrm{L}^{-1}$ for $\mathrm{Cd}, 0.02 \mu \mathrm{g} \mathrm{L}^{-1}$ for $\mathrm{Co}, 0.05 \mu \mathrm{g} \mathrm{L}^{-1}$ for $\mathrm{Cu}$ and $\mathrm{Ni}, 0.2 \mu \mathrm{g} \mathrm{L}^{-1}$ for $\mathrm{Zn}, 0.25 \mu \mathrm{g} \mathrm{L}^{-1}$ for $\mathrm{S}, 2.5 \mu \mathrm{g}$ $\mathrm{L}^{-1}$ for $\mathrm{Fe}$, and $5 \mu \mathrm{g} \mathrm{L}^{-1}$ for Al. The concentrations in our samples were above these detection limits. Since the samples were filtered through $0.45-\mu \mathrm{m}$ filters, the results only include metals dissolved in the solution. Water $\mathrm{pH}$ was measured with a pH meter (WTW pH 340 m, WTW GmbH, Weilheim, Germany), and total organic carbon content (TOC) with Multi N/C® 2100 (Analytik Jena AG, Jena, Germany). Dry mass for both biochars was determined by drying $5 \mathrm{~g}$ of each biochar with three replicates in $105{ }^{\circ} \mathrm{C}$ for $24 \mathrm{~h}$ and calculating the mass lost. Finally, both biochars were analyzed with an FTIR -spectrometer (Thermo Nicolet iS50) in order to compare their surface functional groups.

tion method (Micromeritics Flowsrb II 2300, 1986). The C and $\mathrm{N}$ concentrations were analyzed with an elemental analyzer (Vario Max CN elemental analyzer, Elementar Analysensysteme $\mathrm{GmbH}$, Germany)

\begin{tabular}{ll} 
Norway spruce & Silver birch \\
\hline $600{ }^{\circ} \mathrm{C}$ & $600{ }^{\circ} \mathrm{C}$ \\
$9.25(0.01)$ & $9.75(0.02)$ \\
$221(15)$ & $163(3)$ \\
320 & 260 \\
$72.69 \%(2.74)$ & $81.03 \%(1.86)$ \\
$79.07(0.83)$ & $80.00(0.05)$ \\
$1.19(0.09)$ & $1.39(0.15)$ \\
$66.93(5.51)$ & $58.20(6.38)$
\end{tabular}




\subsection{Calculations and Statistical Analysis}

First, a linear mixed effects model was used to identify whether the concentration has changed related to the blank control at the end of the experiment ( $t=96$ h) (Eq. 1) (Largitte \& Pasquier, 2016). In the analysis, the treatments were considered as fixed effects and replicates as random effects. Linear mixed effects models were applied without a slope parameter. The results were used to identify the treatments that significantly decreased the concentration of metals to selected treatments for further analysis.

$c_{96 h i m r}=\beta_{o i}+\beta_{i m}+\varepsilon_{i m r}$

where $c 96$ i i m r is the concentration of substance $i$ in treatment $m$ in replicate $r$ at time $96 \mathrm{~h}, \beta_{o i}$ is the concentration of substance $i$ in the blank control, $\beta_{i m}$ is the deviation of substance $i$ concentration in treatment $m$ from the blank control, and $\varepsilon_{i m r}$ is the residual term with expectation value of zero.

The concentration decrease during the experiment was used to calculate the cumulative adsorption using Eq. 2:

$Q_{t i}=\frac{\left(C_{i n i i} V_{i n i}-C_{t i} V_{t}\right)-\sum_{k=i n i}^{t}\left(C_{k i} V_{\text {sample }}\right)}{m_{\text {biochar }}}$,

where $Q_{t i}$ is the cumulative adsorption of substance $i$ on biochar ( $\mathrm{mg} \mathrm{g}^{-1}$ biochar), $C_{i n i i}$ and $V_{i n i}$ are the initial concentration of the substance $i\left(\mathrm{mg} \mathrm{L}^{-1}\right)$ and the initial water volume in the sample jars (L), $C_{t i}$ and $V_{t}$ are the same at timepoint $t, C_{k i}$ is the concentration of substance $i$ in the sampling timepoint $(k), V_{\text {sample }}$ is the water volume of a single water sample taken $(20 \mathrm{~mL})$, and $m_{\text {biochar }}(\mathrm{g})$ is the dry mass of the biochar in the jar.

A pseudo-first-order kinetic model was used to describe the adsorption process (Eq. 3) (Largitte \& Pasquier, 2016).

$Q_{i}=Q_{\max }\left(1-e^{-k_{\mathrm{ad}} * t}\right)$,

where $Q_{i}$ is the cumulative adsorption of substance $i$ (mg $\mathrm{g}^{-1}$ biochar) at time $t(\mathrm{~h}), Q_{\max }$ is adsorption capacity $\left(\mathrm{mg} \mathrm{g}^{-1}\right)$, and $k_{\text {ad }}$ is the adsorption rate $\left(\mathrm{g} \mathrm{mg}^{-1} \mathrm{~h}^{-1}\right)$ of substance $i$.

To account for $Q_{\max }$ and $k_{\mathrm{ad}}$ for each treatment, we used nonlinear mixed effects models with Eq. 3 using treatments as fixed and replicates as random effects.
In the first phase, we built a simple base model applying shared $Q_{\max }$ and $k_{\text {ad }}$ for each treatment, and then $Q_{\max }$ and $k_{\text {ad }}$ were allowed to vary between treatments, one at a time. Residual normality was tested for this process. The model performance was evaluated using Akaike Information Criterion (AIC), Bayesian Information Criterion (BIC), and -log likelihood -values and significance of the individual parameter values. Modeling was performed with $\mathrm{R}$, using the lme and nlme -packages (Pinheiro et al., 2021).

\section{Results}

\subsection{Adsorption Experiment: Metal Concentration Changes in Water}

Decreases in metal concentrations in acid sulfate soil drainage water were observed during the experiment, indicating adsorption (Table 3, Fig. 2). The results varied between the treatments and metals. In all biochar treatments, Fe concentrations were significantly lower than in the control at the end of the experiment. In contrast, $\mathrm{S}$ and $\mathrm{Cu}$ concentrations rather increased, suggesting a release of these elements from the adsorbates or additives (Table 3). Aluminum concentration decreased in all treatments not including ash, while $\mathrm{Cd}$ and $\mathrm{Zn}$ concentrations only decreased in treatments including ash. Nickel and Co concentrations decreased in the treatments with spruce biochar, with Co concentration also decreasing with the birch + ash treatment.

Lime addition enhanced the adsorption of Co and $\mathrm{Ni}$ to spruce biochar by $15.7 \%$ and $17.9 \%$ in comparison to both biochar only and biochar with ash by $14.4 \%$ and by $20.9 \%$. No improvements were observed with birch biochar and lime for these two metals. Aluminum and $\mathrm{Fe}$ adsorption was lower with lime than that with only biochar in all cases. Ash addition led to the highest adsorption values observed in this study. Ash with biochar resulted in the highest decreases in metal concentrations (up to 54\% less than control). In treatments without ash, the concentration decrease did not exceed $30 \%$ (Table 4). The highest adsorption was observed for $\mathrm{Fe}, \mathrm{Cd}, \mathrm{Zn}$, and $\mathrm{Cd}$. Aluminum and Ni however had higher adsorption capacities with treatments other than ash. Zinc and Fe showed little difference between the two biochars, 
Table 3 Metal concentrations in water at the last timepoint (96 h). Control values are absolute concentrations and the rest are shown as a difference compared to it. Asterisks denote statistical difference from the blank control $(* p<0.05, * * p<0.01, * * * p<0.0001)$

\begin{tabular}{|c|c|c|c|c|c|c|c|c|}
\hline & $\mathrm{Al}\left(\mu \mathrm{g} \mathrm{L}^{-1}\right)$ & $\mathrm{S}\left(\mathrm{mg} \mathrm{L}^{-1}\right)$ & $\mathrm{Fe}\left(\mu \mathrm{g} \mathrm{L}^{-1}\right)$ & $\mathrm{Cu}\left(\mu \mathrm{g} \mathrm{L}^{-1}\right)$ & $\operatorname{Co}\left(\mu \mathrm{g} \mathrm{L}^{-1}\right)$ & $\mathrm{Cd}\left(\mu \mathrm{g} \mathrm{L}^{-1}\right)$ & $\mathrm{Ni}\left(\mu \mathrm{g} \mathrm{L}^{-1}\right)$ & $\mathrm{Zn}\left(\mu \mathrm{g} \mathrm{L}^{-1}\right)$ \\
\hline Control & 722.5 & 1.75 & 1050 & 3.533 & 0.575 & 0.031 & 1.175 & 11.067 \\
\hline Birch & -117.5 & 2.55 & $-257.5^{* * *}$ & 3.667 & $0.665^{*}$ & $0.0505 * * *$ & $0.975^{* *}$ & $19.93 *$ \\
\hline Birch lime & -42.5 & 4.5 & -17.5 & $4.817 *$ & $0.585^{*}$ & $0.035 * * *$ & $0.975 * *$ & $16.68^{*}$ \\
\hline Birch ash & $1777.5^{* *}$ & $41 * * *$ & $-452.5 * * *$ & $3.317 *$ & -0.0875 & -0.012 & 0.1 & -5.591667 \\
\hline Spruce & -147.5 & 0.025 & $-267.5 * * *$ & $35.217 * * *$ & -0.0475 & 0.0058 & -0.05 & $21.27 * *$ \\
\hline Spruce lime & -87.5 & 0.3 & $-145^{*}$ & $27.467 * * *$ & -0.1375 & 0.0025 & -0.26 & 4.93 \\
\hline Spruce ash & $1187.5^{*}$ & $40.75 * * *$ & $-457.5 * * *$ & $15.967 * * *$ & -0.055 & $-0.017 *$ & -0.015 & -5.417 \\
\hline
\end{tabular}

while $\mathrm{Co}$ and $\mathrm{Cd}$ had relatively high differences, $\mathrm{Co}$ in favor of birch and $\mathrm{Cd}$ of spruce. Based on the observed adsorption (Fig. 3), Al, Fe, Co, Zn, and Cd were chosen for the analysis of adsorption kinetics.

\subsection{Adsorption Kinetics}

Adsorption rate $\left(k_{\mathrm{ad}}\right)$ and capacity $\left(Q_{\max }\right)$ for the selected metals were computed with Eq. 2 (Table 5). Both adsorption parameters were larger for $\mathrm{Al}$ and $\mathrm{Fe}$ having higher initial concentrations than for $\mathrm{Co}, \mathrm{Zn}$, and $\mathrm{Cd}$. The presence of ash increased statistically significantly $Q_{\max }$-values for Co and Cd. However, spruce biochar with lime had the highest $Q_{\max }$ for Fe. Cadmium showed the lowest adsorption capacity.

\subsection{TOC, $\mathrm{pH}$, and FTIR}

Both TOC and $\mathrm{pH}$ changed during the experiment (Table 6). All biochar treatments showed an increase in $\mathrm{pH}$ compared to control reaching a value well above the critical 5.5 threshold, with biochars themselves causing the smallest increases, and the lime combined with biochar the largest ones. Birch biochar caused a larger $\mathrm{pH}$ increase in all treatments than the spruce biochar.

There was variation in TOC concentrations between the treatments. The treatments containing only biochar had the largest TOC concentrations, larger than that in controls. Adding ash or lime decreased the TOC concentrations below the control value, except in the case of birch biochar with lime. Ash decreased TOC more than lime; birch biochar with ash had the lowest TOC value overall.

FTIR analysis found mainly similar spectra for both biochar surfaces, with a single large difference area (Fig. 4). There were similar structures around wavelengths $2850-2950 \mathrm{~cm}^{-1}, 2100-2200 \mathrm{~cm}^{-1}$, and $1600 \mathrm{~cm}^{-1}$, which could refer to aldehydes, triple bonds, and carbonyl groups $(\mathrm{C}=\mathrm{O})$ respectively. The greatest difference occurred around $1000-1450 \mathrm{~cm}^{-1}$, where birch gave a large, broad peak and spruce showed practically nothing. These peaks observed in birch biochar could represent various esters, ethers and alcohols (C-O) or even $\mathrm{C}-\mathrm{N}$ and $\mathrm{S}=\mathrm{O}$ stretchings. Aliphatic $\mathrm{C}-\mathrm{H}$ bonds and non-aromatic $\mathrm{C}=\mathrm{C}$ bonds also occur in this area. Spruce biochar had larger specific surface area than birch biochar (Table 2).

\section{Discussion}

Our study indicated that biochar can recover metal ions from acid sulfate soil runoff water, thus supporting our first hypothesis. The largest observed concentration decreases were for $\mathrm{Al}, \mathrm{Fe}, \mathrm{Cd}$, and $\mathrm{Zn}$, of which $\mathrm{Al}, \mathrm{Cd}$, and $\mathrm{Zn}$ are particularly toxic in water ecosystems (Sutela et al. 2012). Both biochars with ash addition could adsorb $\mathrm{Fe}, \mathrm{Co}, \mathrm{Cd}$, and $\mathrm{Zn}$ simultaneously, with spruce biochar also adsorbing some $\mathrm{Ni}$. However, the results do not fully support our second hypothesis, as lime and ash additions did not always improve the metal adsorption. All biochar treatments increased the $\mathrm{pH}$ of drainage water above the critical threshold limit of 5.5 supporting our third hypothesis on the neutralizing capacity of biochar.

\subsection{Difference Between the Biochars}

Both biochars adsorbed metals; however, spruce biochar had a slightly higher adsorption than the birch 
biochar in most of the treatments (Fig. 3). In treatments with biochar only, the adsorption of $\mathrm{Al}, \mathrm{Fe}, \mathrm{Co}$, and $\mathrm{Ni}$ to spruce biochar was higher than for birch biochar. This difference was even larger for Co and $\mathrm{Ni}$, which had no adsorption with the treatment containing only birch biochar (Table 4).

FTIR spectra for our biochars were similar in most parts, and featured peaks typical to biochar (Zhang et al., 2018, Parin et al., 2020). However, there are great differences in peak size at 700-900 nm and 1500-1700 nm, as well as a large, wide peak for birch biochar at 900-1500 $\mathrm{nm}$ which does not appear for spruce biochar. Despite the huge differences here, spruce biochar was more efficient as an adsorbent in our samples overall. Therefore, these differing areas do not explain the differences in biochar adsorption efficiencies, and we must consider other adsorption mechanisms as the major cause here. One such thing could be the surface sorption, since spruce biochar had a larger specific surface area (Table 2). Another possibility is the mechanism via precipitation, which Ambaye et al. (2020) point out as being stronger at alkaline biochars produced in temperatures higher than $300{ }^{\circ} \mathrm{C}$, which matches our biochars.

\subsection{Ash and Lime Differences vs. Biochar Only (pH)}

Ash and lime affected the adsorption, with ash generally resulting in higher adsorption (Table 4), with the exception of $\mathrm{Co}$ and $\mathrm{Zn}$. This could be at least partially due to the differences in $\mathrm{pH}$ increases between treatments. Kołodyńska et al. (2012) found that the maximum adsorption efficiency for $\mathrm{Cu}$ was at $\mathrm{pH}$ of about 5.0. Below this down to $\mathrm{pH}$ of 1.0, the $\mathrm{Cu}$ is in the easily adsorbed $\mathrm{Cu}$ (II) form, while at higher $\mathrm{pH}$, the formation of hydroxide complexes and precipitation start to hinder the adsorption. This might explain the lack of $\mathrm{Cu}$ adsorption in our study, since our $\mathrm{pH}$ values were well over 5 in all samples (Table 6). For $\mathrm{Zn}(\mathrm{II})$, the optimal $\mathrm{pH}$ range was determined to be 1-7 in Kołodyńska et al. (2012). Our samples fit into this range, and the $\mathrm{Zn}$ adsorption was the second highest of all the metals we tested at the treatments with biochar and ash. In these samples, the $\mathrm{pH}$ was $6.8-7$, at the top end of the optimal range, while the biochar with lime went over this range to $\mathrm{pH} 7.2-7.4$ and had lower adsorption. However, our samples with only biochar had lower $\mathrm{pH}$ of 6.2-6.5 but did not have higher adsorption than the lime samples with high $\mathrm{pH}$. This is also still higher than the optimal $\mathrm{pH}$ of 5.0 determined for $\mathrm{Zn}$ adsorption by Kołodyńska et al. (2012). Their maximum adsorption efficiency obtained at this optimal $\mathrm{pH}$ for $\mathrm{Zn}$ was $4.25 \mathrm{mg} \mathrm{g}^{-1}$, while our highest $Q_{\max }$ was 0.039 , a substantial difference. Therefore, there must be factors other than this also affecting the final adsorption capacity, such as the initial metal concentration of the water and the physicochemical properties of biochar.

\subsection{Initial Metal Concentrations and Competing Adsorption}

In our experiment, the initial metal concentrations in the water were at the lower end of the range observed for acid sulfate soils, especially for $\mathrm{Cd}$ and Co (Hovinen et al., 2012). The highest metal concentrations in our water were $\mathrm{Al}\left(722.5 \mu \mathrm{g} \mathrm{L}^{-1}\right)$ and $\mathrm{Fe}\left(1050 \mu \mathrm{g} \mathrm{L}^{-1}\right)$, which have been reported to range

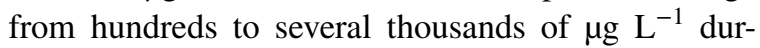
ing spring peak runoff in acid sulfate soils (Saarinen et al., 2013). The rather low initial concentrations in our experiment may be due to the sampling time, which missed the peak flow period. The preceding winter was also exceptionally mild with little snow cover. Our low initial concentration reflected into adsorption, which showed relatively low values for Cd in particular: our highest $Q_{\max }$ was $0.022 \mathrm{mg} \mathrm{g}^{-1}$ in spruce biochar and ash treatment, while $\mathrm{Li}$ et al. (2017) give it a range of $0.3-39.1 \mathrm{mg} \mathrm{g}^{-1}$. Likewise, Ni has a $Q_{\max }$ of $19.2-33.4 \mathrm{mg} \mathrm{g}^{-1}$ according to them, while in our experiment, $\mathrm{Ni}$ adsorption was very low and therefore it was not included in the kinetics modeling. Chen et al. (2011) reported $Q_{\max }$ to be $6.79-12.52 \mathrm{mg} \mathrm{g}^{-1}$ for $\mathrm{Cu}$ and $4.54-11 \mathrm{mg} \mathrm{g}^{-1}$ for $\mathrm{Zn}$, respectively. In our study, $\mathrm{Cu}$ concentrations increased; however, $\mathrm{Zn}$ had $Q_{\max }$ of $1-5.9 \mathrm{mg} \mathrm{g}^{-1}$, resulting in up to $50 \%$ reduction compared to control and reaching the range discovered by Chen et al. (2011). It is important to note that these studies used biochar from different feedstocks and manufacturing temperatures (hardwood at $450{ }^{\circ} \mathrm{C}$, corn straw at $600^{\circ} \mathrm{C}$ ), so direct comparisons are not possible, and some differences are expected. These results point to the known fact that the adsorption efficiency depends on the initial concentration of the pollutant, higher concentrations leading to higher adsorption and vice versa (Saarela et al., 2020, Wang et al., 2020). This is supported by the fact that in our study, $\mathrm{Al}$ and Fe have 

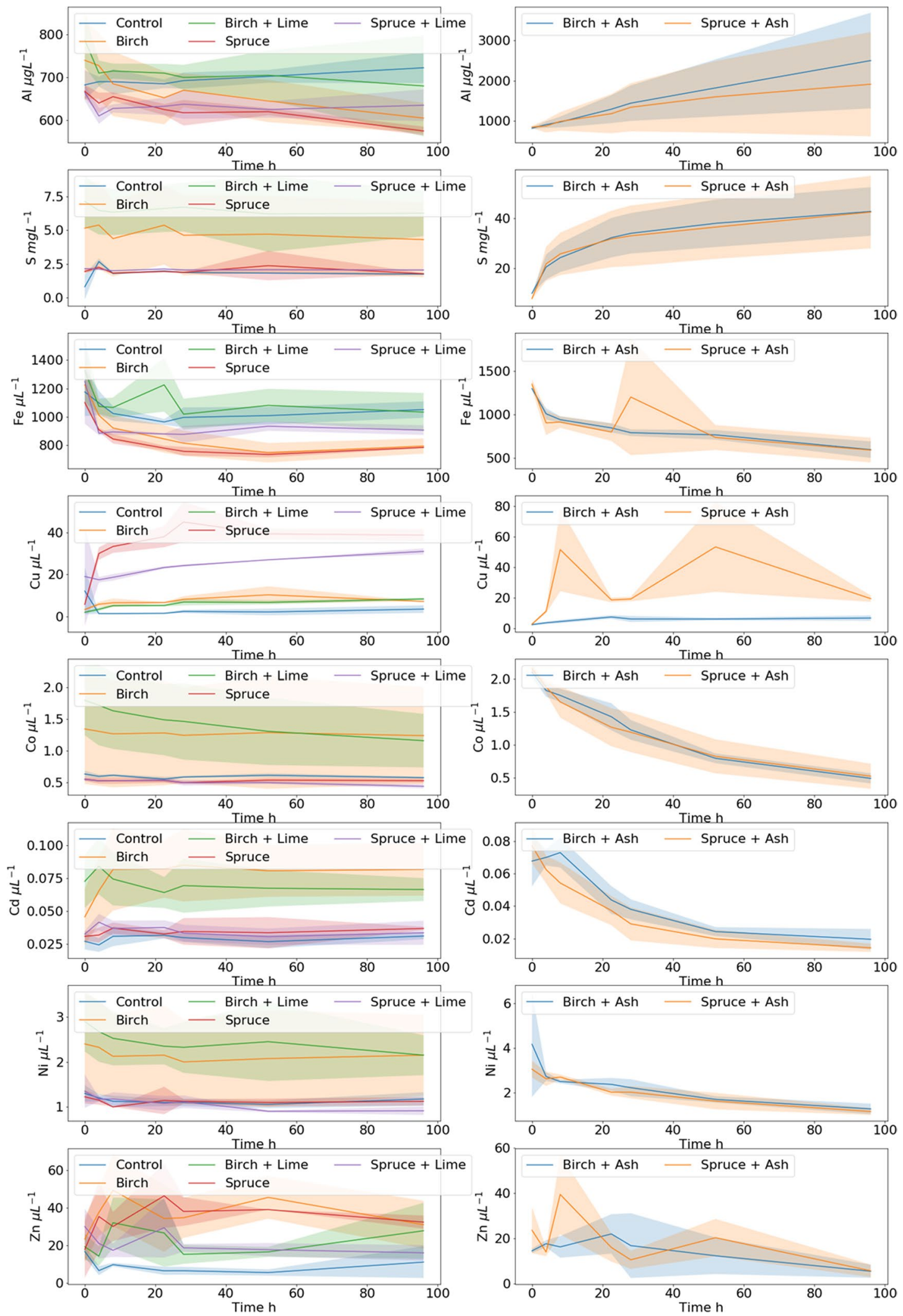
4Fig. 2 Metal and S concentration in water during the experiment. Ash treatments have either larger values or opposing trends, so they are separated from the rest. The initial value represents a blank sample. Decrease in the concentration is shown by a downwards facing line, which indicates metal removal via adsorption into biochar. Shaded areas indicate the range of individual values at the timepoints

multiple times higher initial concentrations than Co, $\mathrm{Cd}, \mathrm{Ni}$, and $\mathrm{Zn}$ in our samples, and also show clearly higher concentration decreases in water as well as $Q_{\max }$ values overall. Increasing initial metal concentrations might decrease the percentage of metal adsorbed but increase the absolute adsorbed amount ( $\mathrm{mg} \mathrm{g}^{-1}$ biochar) (Abdullah et al., 2019). Therefore, the adsorption capacities and rates observed here could be larger at the actual sites, especially during the peak flow periods with possibly multiple times higher metal concentrations.

Another noteworthy factor weakening metal adsorption in a multi-metal solution is their competing adsorption, which for example has been shown to suppress $\mathrm{Cd}$ adsorption in favor of other metals (Park et al., 2016; Zhao et al., 2019). Park et al. (2016) discovered that competitive adsorption decreased the maximum adsorption capacity of $\mathrm{Cd}$ to sesame straw biochar from 86 to $5 \mathrm{mg} \mathrm{g}^{-1}$. Likewise, $\mathrm{Zn}$ adsorption decreased from 34 to $7 \mathrm{mg} \mathrm{g}^{-1}$. Our sample water included a range of multiple possibly competing metals, which could explain the lower adsorption values together with our relatively low initial metal concentrations.

\subsection{Main Adsorption Mechanisms and Desorption}

Increased adsorption with ash addition, when compared to biochar only samples, indicates the beneficial effect of higher $\mathrm{pH}$ to the adsorption. This would suggest that electrostatic attraction is a major pathway in the adsorption (Cheng et al., 2021), especially for Co and $\mathrm{Ni}$, where the highest $\mathrm{pH}$ treatment (biochar with lime) clearly had the highest adsorption. However, we have multiple cases of ash treatment having the highest adsorption, and for $\mathrm{Al}$ and $\mathrm{Fe}$, we have adsorption worse than with biochar only with lime addition. In these cases, it might be possible that the $\mathrm{pH}$ increased too high, and instead turned detrimental to the adsorption process of these metals (Kołodyńska et al., 2012, Zhou et al., 2021).

Another noteworthy fact is the larger specific surface area of the spruce biochar $\left(320 \mathrm{~m}^{2} \mathrm{~g}^{-1}\right)$ compared to the birch biochar $\left(260 \mathrm{~m}^{2} \mathrm{~g}^{-1}\right)$. Considering that birch biochar only adsorbs $\mathrm{Al}$ and $\mathrm{Fe}$ without ash addition, and that those 2 have the highest initial concentrations and adsorptions, surface adsorption could be a major pathway. $\mathrm{Al}$ and Fe would adsorb better due to their higher initial concentration, and thus dominate over other metals. Birch biochar could not adsorb other metals, while the larger specific surface area of spruce biochar would mean that there is room for $\mathrm{Co}$ and $\mathrm{Zn}$ adsorption. With ash or lime present, the increasing $\mathrm{pH}$ then would open new pathways, such as electrostatic interaction discussed above. No longer limited by the heavy competition and their low initial concentrations, $\mathrm{Cd}$ and $\mathrm{Zn}$ adsorption occurs strongly. The weak adsorption of $\mathrm{Cd}$ and $\mathrm{Zn}$ under heavier competition would follow the results shown by Park et al. (2016). Thus, we theorize that the major adsorption pathways in our samples are dominated by surface adsorption at first, while the increase in $\mathrm{pH}$ enhances the electrostatic and ion exchange pathways. Alkaline conditions and the high pyrolysis temperatures of our biochar also favor surface precipitation (Ambaye et al. (2020).

The final factor to consider would be the stability of the metals adsorbed into the biochar, and the possibility of various changes in site $\mathrm{pH}$ and ionic strength of the adsorbent causing desorption. Zhou
Table 4 Percentage decreases of different metal concentrations when compared to the control values at the end of the experiment $(96 \mathrm{~h})$. Treatments, where no statistically significant decrease was achieved, have been left blank/omitted

\begin{tabular}{llllllll}
\hline & Control $\left(\mu \mathrm{g} \mathrm{L}^{-1}\right)$ & Birch & Birch lime & Birch ash & Spruce & Spruce lime & Spruce ash \\
\hline $\mathrm{Al}$ & 722.5 & -16.26 & -5.88 & & -20.42 & -12.11 & \\
$\mathrm{Fe}$ & 1050 & -24.52 & -1.67 & -43.10 & -25.48 & -13.81 & -43.57 \\
$\mathrm{Co}$ & 0.575 & & & -15.22 & -8.26 & -23.91 & -9.57 \\
$\mathrm{Cd}$ & 0.031 & & -37.10 & & & -54.03 \\
$\mathrm{Ni}$ & 1.175 & & & -4.26 & -22.13 & -1.28 \\
$\mathrm{Zn}$ & 11.07 & & -50.53 & & & -48.95 \\
\hline
\end{tabular}



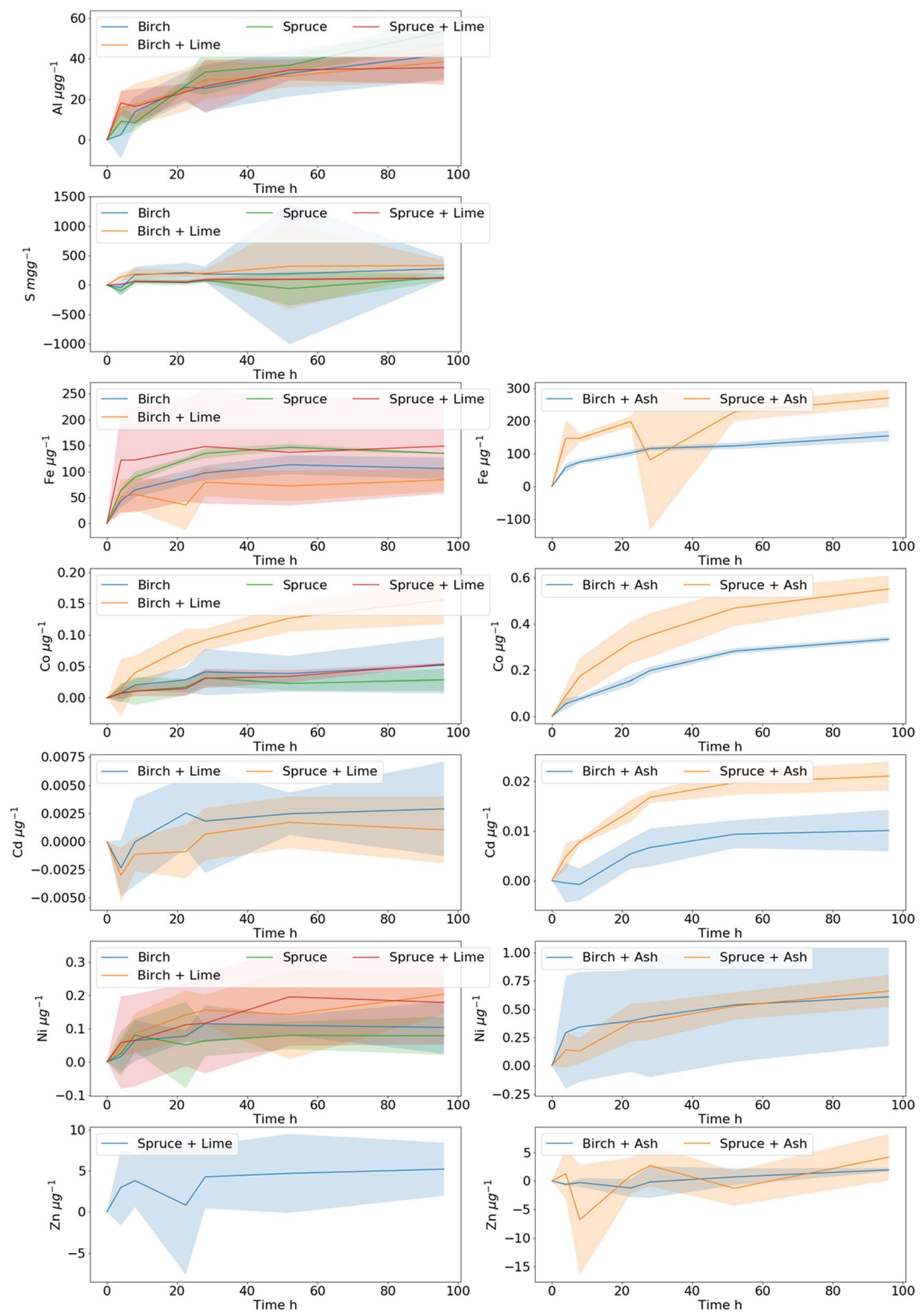
4Fig. 3 The metal concentrations in biochar, calculated from the concentration changes in water. Upward facing lines indicate accumulation of the metal into biochar via adsorption. Cases where either no adsorption was observed or where desorption dominated over it were omitted

et al. (2021) state that in an alkaline environment, most heavy metals are in combined form with strong stability. However, Zhou et al. (2021) note that the adsorption process is reversible under the right circumstances, such as a drop in $\mathrm{pH}$. Thus, our $\mathrm{pH}$ increasing additives could have the additional benefit of potentially reducing the metal desorption. Further study about desorption would be important to determine the function of biochar filters in field conditions where water $\mathrm{pH}$ and metal concentrations vary.

In our experiment, spruce biochar with ash could adsorb $\mathrm{Fe}, \mathrm{Co}, \mathrm{Cd}$, and $\mathrm{Zn}$ simultaneously. These are all commonly leached from acid sulfate sites and contribute to the damage of aquatic environments (Roos \& Åström, 2005, Fältmarsch et al., 2007). Fe oxidation in acid water releases protons and thus reinforces acidification. High concentrations of $\mathrm{Fe}$ can also cause physical and environmental stress by coagulating on fish gills or eggs and on the bottom sediments. $\mathrm{Zn}$ and Co are toxic in high concentrations, and $\mathrm{Cd}$ is a carcinogen that can also cause malformations in fish bones. Fältmarch et al. (2007) found Al, Zn, and Fe accumulation in cow's milk in acidic soil drainage area, which indicates a possibility for human health risks as well. $\mathrm{Al}$ adsorption was not improved by ash, but it could be adsorbed with either biochar or biochar and lime. Al adsorption is important as well, because $\mathrm{Al}$ is abundant in Finnish soils and it has harmful effects on fish at high concentrations. These include failure of breathing and osmoregulation, accumulation, and various difficulties in reproduction (Fältmarsch et al., 2007; Gensemer et al., 2018). Our preliminary laboratory investigations suggest that biochar-based adsorption method can decrease metal concentrations from runoff water in acid sulfate peatland forests, while also lowering the drainage water acidity and thus toxicity to water biota. This is the first step of developing a biochar-based water protection tool for acid sulfate sites, and further work with an actual-scale biochar reactor in a laboratory and field conditions is needed.
Table 5 Adsorption rate $\left(k_{\mathrm{ad}}\right)$ and adsorption capacity $\left(Q_{\max }\right)$ for selected metals were computed with Eq. 1 The uppermost $Q_{\max }$ line for each metal shows an absolute value, and the rest are shown as difference to this value

\begin{tabular}{|c|c|c|c|c|c|c|c|}
\hline & Value & SE & $p$ value & & Value & SE & $p$ value \\
\hline \multicolumn{8}{|c|}{$\mathrm{Co}$} \\
\hline$k_{\mathrm{ad}}$ & 0.047 & 0.006 & $<0.001$ & $k_{\mathrm{ad}}$ & 0.035 & 0.0026 & $<0.001$ \\
\hline$Q_{\max }$ birch & 38.88 & 2.855 & $<0.001$ & $Q_{\max }$ birch ash & 0.329 & 0.014 & $<0.001$ \\
\hline$Q_{\max }$ birch lime & -0.148 & 3.437 & 0.966 & $Q_{\max }$ spruce & -0.295 & 0.0176 & $<0.001$ \\
\hline$Q_{\max }$ spruce & 6.78 & 3.448 & 0.0525 & $\begin{array}{l}Q_{\max } \text { spruce } \\
\text { lime }\end{array}$ & -0.283 & 0.0174 & $<0.001$ \\
\hline$Q_{\max }$ spruce lime & -1.1 & 3.437 & 0.749 & $\begin{array}{l}Q_{\max } \text { spruce } \\
\text { ash }\end{array}$ & 0.24 & 0.017 & $<0.001$ \\
\hline \multicolumn{8}{|c|}{$\mathrm{Zn}$} \\
\hline$k_{\mathrm{ad}}$ & 0.088 & 0.018 & $<0.001$ & $k_{\mathrm{ad}}$ & 0.019 & 0.025 & 0.447 \\
\hline$Q_{\max }$ birch & 110.25 & 12.56 & $<0.001$ & $Q_{\max }$ birch ash & 1.009 & 1.785 & 0.578 \\
\hline$Q_{\max }$ birch lime & -19.61 & 17.75 & 0.271 & $\begin{array}{l}Q_{\max } \text { spruce } \\
\text { lime }\end{array}$ & 5.907 & 4.402 & 0.1844 \\
\hline$Q_{\max }$ birch ash & 25.65 & 17.73 & 0.15 & $\begin{array}{l}Q_{\max } \text { spruce } \\
\text { ash }\end{array}$ & 1.527 & 2.584 & 0.5565 \\
\hline$Q_{\max }$ spruce & 32.86 & 17.11 & 0.056 & $\mathrm{Cd}$ & & & \\
\hline$Q_{\max }$ spruce lime & 197.03 & 23.83 & $<0.001$ & $k_{\mathrm{ad}}$ & 0.025 & 0.007 & $<0.001$ \\
\hline \multirow[t]{3}{*}{$Q_{\max }$ spruce ash } & 128.072 & 18.31 & $<0.001$ & $\begin{array}{l}Q_{\max } \text { birch } \\
\text { lime }\end{array}$ & 0.008 & 0.002 & $<0.001$ \\
\hline & & & & $Q_{\max }$ birch ash & 0.007 & 0.002 & 0.0039 \\
\hline & & & & $\begin{array}{l}Q_{\max } \text { spruce } \\
\text { ash }\end{array}$ & 0.014 & 0.002 & $<0.001$ \\
\hline
\end{tabular}


Table 6 TOC and $\mathrm{pH}$ value averages in samples at the end of the experiment

\begin{tabular}{lll}
\hline Sample & $\mathrm{pH}$ & TOC $\left(\mathrm{mg} \mathrm{L}^{-1}\right)$ \\
\hline Control & 4.9 & 26.4 \\
Birch & 6.5 & 29.4 \\
Birch lime & 7.4 & 27.3 \\
Birch ash & 7.0 & 19.5 \\
Spruce & 6.2 & 26.9 \\
Spruce lime & 7.2 & 22.7 \\
Spruce ash & 6.8 & 21.6 \\
\hline
\end{tabular}

\section{Conclusions}

Biochar was able to reduce metal concentrations, including $\mathrm{Al}, \mathrm{Fe}, \mathrm{Cd}, \mathrm{Zn}$, from water draining from acid sulfate soil area and decreased water acidity reaching $\mathrm{pH}$ values well above the critical 5.5 limit of deleterious impact on aquatic biota. Our hypotheses that biochar could adsorb metal from water and neutralize water acidity were clearly met, but the second hypothesis about lime and ash increasing the adsorption does not apply in all cases. The recovery of $\mathrm{Fe}, \mathrm{Cd}$, and $\mathrm{Zn}$ can be further improved by adding ash, which, on the other hand, can lead to the release of $\mathrm{Cu}$. Spruce biochar performed overall better than birch, adsorbing more metals without the ash additive. Spruce biochar with ash addition could simultaneously adsorb $\mathrm{Fe}, \mathrm{Co}, \mathrm{Cd}, \mathrm{Ni}$, and $\mathrm{Zn}$, reaching up to $48.95 \%$ adsorption of $\mathrm{Zn}$. Birch biochar with ash simultaneously adsorbed $\mathrm{Fe}, \mathrm{Co}, \mathrm{Cd}$, and $\mathrm{Zn}$, reaching up to $50.53 \%$ adsorption for $\mathrm{Zn}$. Water was collected from the field when the metal concentrations were rather low. This possibly leads to lower adsorption in our experiment, and therefore the adsorption is likely higher at actual sites during heavy runoff episodes. In Finland, the leaching of $\mathrm{Fe}$ and $\mathrm{Al}$ cause the most harmful effects in watercourses because of their high relative abundance. Therefore, adsorption-based water protection with biochar and $\mathrm{pH}$-increasing additives have the potential to become a viable water protection method in the problematic acid-sulfate soil areas. Furthermore, larger-scale work in laboratory and field conditions is needed. Another factor worth studying is how long does the metal

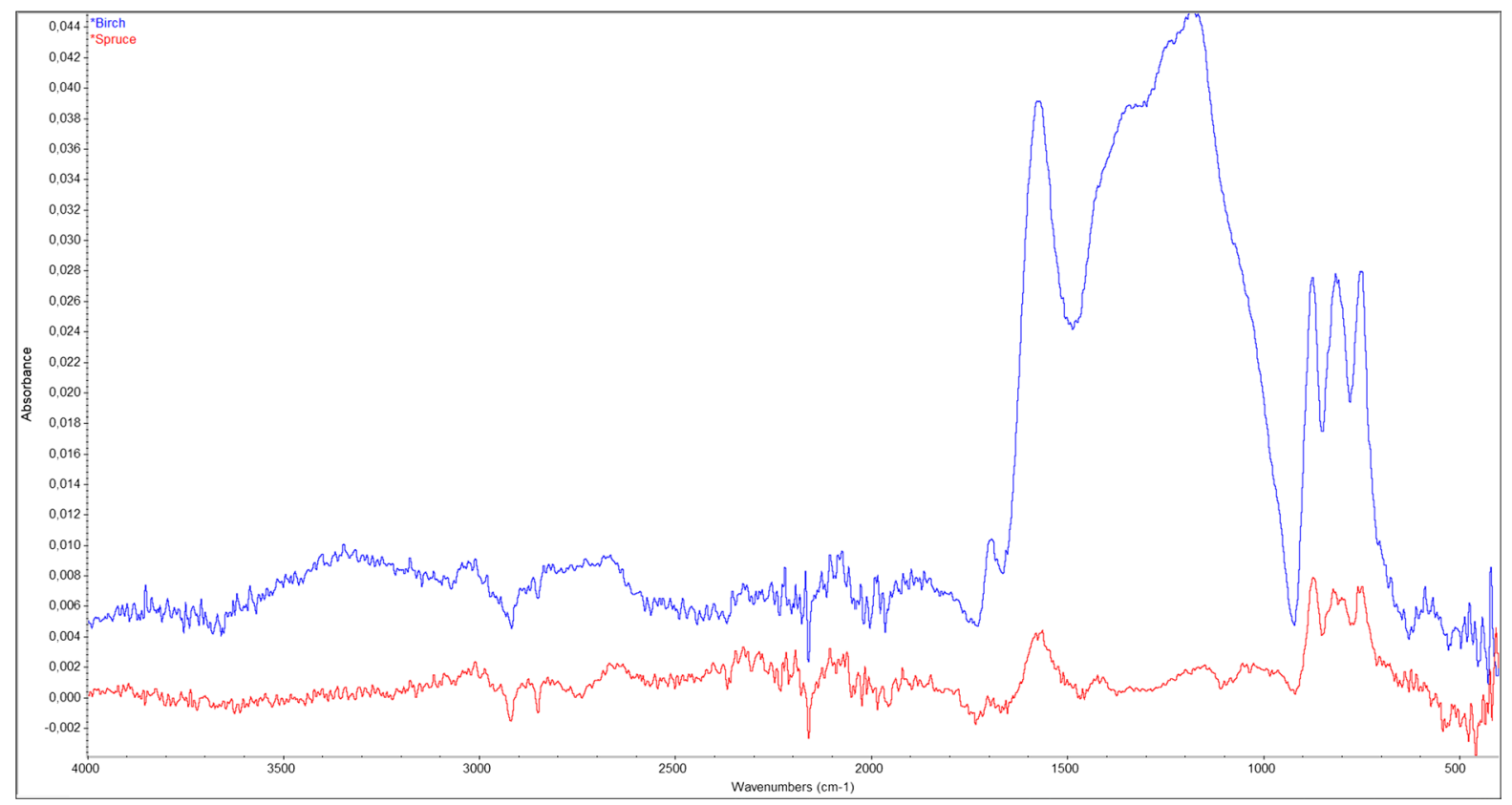

Fig. 4 FTIR spectra of birch (blue) and spruce (red) biochar. Upwards or downwards peaks from the baseline indicate the presence of a certain functional group, depending on the wave- number of the peak. Our biochars are mainly similar, but the difference around $1000-1500 \mathrm{~cm}^{-1}$ indicates a structural difference 
adsorption into biochar last, and whether and how fast desorption happens.

Supplementary Information The online version contains supplementary material available at https://doi.org/10.1007/ s11270-021-05407-6.

Acknowledgements We thank Taija Saarela and Mikko Selenius for help in the laboratory work.

Author Contribution Conceptualization: Marjo Palviainen, Annamari Lauren, ...; Methodology: Niko Kinnunen, Marjo Palviainen, Annamari Lauren, ...; Formal analysis and investigation: Niko Kinnunen, ...; Writing-original draft preparation: Niko Kinnunen, Marjo Palviainen, Annamari Lauren, Jukka Pumpanen; Writing — review and editing: Niko Kinnunen, Marjo Palviainen, Annamari Lauren, Jukka Pumpanen, Tiina M. Nieminen, ...; Funding acquisition: Marjo Palviainen, ...; Resources: Marjo Palviainen, Jukka Pumpanen, ...; Supervision: Marjo Palviainen, Annamari Lauren, Jukka Pumpanen.

Funding Open access funding provided by University of Eastern Finland (UEF) including Kuopio University Hospital. This study was funded by Maa- ja vesitekniikan tuki ry.

Availability of Data and Material The data will be provided as a supplementary material, if the manuscript is accepted for the journal.

\section{Code Availability N/A.}

\section{Declarations}

Conflict of Interest The authors declare no competing interests.

Open Access This article is licensed under a Creative Commons Attribution 4.0 International License, which permits use, sharing, adaptation, distribution and reproduction in any medium or format, as long as you give appropriate credit to the original author(s) and the source, provide a link to the Creative Commons licence, and indicate if changes were made. The images or other third party material in this article are included in the article's Creative Commons licence, unless indicated otherwise in a credit line to the material. If material is not included in the article's Creative Commons licence and your intended use is not permitted by statutory regulation or exceeds the permitted use, you will need to obtain permission directly from the copyright holder. To view a copy of this licence, visit http://creativecommons.org/licenses/by/4.0/.

\section{References}

Abdullah, N., Yusof, N., Lau, W. J., Jaafar, J., \& Ismail, A. F. (2019). Recent trends of heavy metal removal from water/wastewater by membrane technologies. Journal of
Industrial and Engineering Chemistry, 76, 17-38. https:// doi.org/10.1016/j.jiec.2019.03.029

Ahmadvand, M., et al. (2018). The relationship between the characteristics of biochar produced at different temperatures and its impact on the uptake of $\mathrm{NO}_{3^{-}}-\mathrm{N}$. Environmental Health Engineering and Management, 5(2), 67-75. https://doi.org/10.15171/EHEM.2018.10

Andriesse, W., \& van Mensvoort, M. E. F. (2002). Distribution and extent of acid sulphate soils. In R. Lal (Ed.), Encyclopedia of soil science (pp. 1-6). Marcel Dekker Inc.

Ambaye, T. G., Vaccari, M., van Hullebusch, E. D., et al. (2020). Mechanisms and adsorption capacities of biochar for the removal of organic and inorganic pollutants from industrial wastewater. International Journal of Environmental Science and Technology. https://doi.org/10.1007/ s13762-020-03060-w

Chen, X., et al. (2011). Adsorption of copper and zinc by biochars produced from pyrolysis of hardwood and corn straw in aqueous solution. Bioresource Technology, 102(19), 8877-8884. https://doi.org/10.1016/j.biortech. 2011.06.078

Cheng, N., Wang, B., Wu, P., Lee, X., Xing, Y., Chen, M., \& Gao, B. (2021). Adsorption of emerging contaminants from water and wastewater by modified biochar: A review. Environmental Pollution, 273, 116448. https://doi.org/10. 1016/j.envpol.2021.116448

Dang, T., Mosley, L. M., Fitzpatrick, R., \& Marschner, P. (2015). Organic materials differ in ability to remove protons, iron and aluminium from acid sulfate soil drainage water. Water, Air, and Soil Pollution, 226, 357. https://doi. org/10.1007/s11270-015-2595-z

Fältmarsch, R. M., Åström, M. E., \& Vuori, K.-M. (2007). Environmental risks of metals mobilised from acid sulphate soils in Finland: A literature review. Boreal Env. Res., 13, 444-456.

Garcia-Chevesich, P., García, V., Martínez, G., Zea, J., Ticona, J., Alejo, F., Vanneste, J., Acker, S., Vanzin, G., Malone, A., Smith, N. M., Bellona, C., \& Sharp, J. O. (2020). Inexpensive organic materials and their applications towards heavy metal attenuation in waters from southern Peru. Water, 12, 2948. https://doi.org/10.3390/w12102948

Gensemer, R. W., Gondek, J. C., Rodriquez, P. H., Arbildua, J. J., Stubblefield, W. A., Cardwell, A. S., Santore, R. C., Ryan, A. C., Adams, W. J., \& Nordheim, E. (2018). Evaluating the effects of $\mathrm{pH}$, hardness, and dissolved organic carbon on the toxicity of aluminum to freshwater aquatic organisms under circumneutral conditions. Environmental Toxicology and Chemistry, 37, 49-60. https://doi.org/10.1002/etc.3920

Hovinen, T., et al. (2012). Happamien Sulfaattimaiden Vesistövaikutusten Seuranta Vuosina, 2009-2011, 1-35.

Inyang, M., et al. (2012). Removal of heavy metals from aqueous solution by biochars derived from anaerobically digested biomass. Bioresource Technology, 110, 50-56. https://doi.org/10.1016/j.biortech.2012.01.072

Kołodyńska, D., Wnętrzak, R., Leahy, J. J., Hayes, M. H. B., Kwapiński, W., \& Hubicki, Z. (2012). Kinetic and adsorptive characterization of biochar in metal ions removal. Chemical Engineering Journal, 197, 295-305. https://doi.org/10.1016/j.cej.2012.05.025 
Lafdani, E. K. et al. (2020) Purification of forest clear-cut runoff water using biochar: A meso-scale laboratory column experiment. Water (Switzerland), 12(2). https://doi. org/10.3390/w12020478

Largitte, L., \& Pasquier, R. (2016). A review of the kinetics adsorption models and their application to the adsorption of lead by an activated carbon. Chemical Engineering Research and Design, 109, 495-504. https://doi.org/ 10.1016/j.cherd.2016.02.006

Li, H. et al. (2017) Mechanisms of metal sorption by biochars: Biochar characteristics and modifications. Chemosphere. Elsevier Ltd, pp. 466-478. https://doi.org/10. 1016/j.chemosphere.2017.03.072

Micromeritics Flowsrb II 2300. 1986. Micromeritics Instrument Corporation: Atlanta, GA, USA

Mullins, C., Smith, K. 2001. Soil and environmental analysis: Physical methods, revised, and expanded, New York: CRC Press, eBook Collection (EBSCOhost), EBSCOhost, viewed 20 March 2021

Nieminen, M., et al. (2018). Could continuous cover forestry be an economically and environmentally feasible management option on drained boreal peatlands? Forest Ecology and Management, 424, 78-84. https://doi.org/ 10.1016/j.foreco.2018.04.046

Nordmyr, L., Åström, M., \& Peltola, P. (2008). Metal pollution of estuarine sediments caused by leaching of acid sulphate soils. Estuarine, Coastal and Shelf Science, 76(1), 141152. https://doi.org/10.1016/j.ecss.2007.07.002

Palko, J. (1994). Acid sulfate soils and their agricultural and environmental problems in Finland. Doctoral dissertation. Acta Universitatis Ouluensis. 58p

Parın, F. N., Yıldırım, K., \& Terzioğlu, P. (2020). Biochar loaded chitosan/gelatin/ poly(ethylene glycol) biocomposite beads: Morphological, thermal and swelling properties. Journal of Innovative Science and Engineering., 4(2), 56-68. https://doi.org/10.38088/jise.743635

Park, J. H., et al. (2016). Competitive adsorption of heavy metals onto sesame straw biochar in aqueous solutions. Chemosphere, 142, 77-83. https://doi.org/10.1016/j.chemo sphere.2015.05.093

Pinheiro, J., Bates, D., DebRoy, S., Sarkar, D., \& R Core Team. (2021). nlme: Linear and nonlinear mixed effects models. $\mathrm{R}$ package version 3.1-153, https://CRAN.R-project.org/ package $=$ nlme.ref)

Ramalingham Senthilkumar and Donipathi Mogili Reddy Prasad (May 21st 2020). Sorption of heavy metals onto biochar, applications of biochar for environmental safety. Ahmed A. Abdelhafez and Mohammed H. H. Abbas, IntechOpen. https://doi.org/10.5772/intechopen.92346

Roos, M., \& Åström, M. (2005). Hydrochemistry of rivers in an acid sulphate soil hotspot area in western Finland. Agricultural and Food Science, 14(1), 24-33. https://doi. org/10.2137/1459606054224075

Saarela, T., et al. (2020). Biochar as adsorbent in purification of clear-cut forest runoff water: Adsorption rate and adsorption capacity. Biochar, 2(2), 227-237. https://doi.org/10. 1007/s42773-020-00049-z

Saarinen, T., Mohämmädighävam, S., Marttila, H., \& Kløve, B. (2013). Impact of peatland forestry on runoff water quality in areas with sulphide-bearing sediments; How to prevent acid surges. Forest Ecology and Management, 293, 17-28. https://doi.org/10.1016/j.foreco.2012.12.029

Sallinen, A., et al. (2019). Undrained peatland areas disturbed by surrounding drainage: A large scale GIS analysis in Finland with a special focus on AAPA mires. Mires and Peat, 24, 1-22. https://doi.org/10.19189/MaP.2018.AJB. 391

Shin, JDu., et al. (2018). Adsorption characteristics of ammonium nitrogen and plant responses to biochar pellet. Sustainability (switzerland), 10(5), 1-11. https://doi.org/10. 3390/su10051331

Sikström, U. and Hökkä, H. (2016) Interactions between soil water conditions and forest stands in boreal forests with implications for ditch network maintenance. Silva Fennica, 50(1). https://doi.org/10.14214/sf.1416

Sutela, T. et al. (2012) Suomen ympäristökeskus Happamien sulfaattimaiden aiheuttamat vesistövaikutukset ja kalakuolemat Suomessa, in. Available at: www.ymparisto.fi/ julkaisut

Thompson, K. A., et al. (2016). Environmental comparison of biochar and activated carbon for tertiary wastewater treatment. Environmental Science and Technology, 50(20), 11253-11262. https://doi.org/10.1021/acs.est.6b03239

Vuori, K.-M., Bäck, S., Hellsten, S.,Holopainen, A.-L., Järvinen, M., Kauppila, P., Kuoppala, M., Lax, H-G., Lepistö, L., Marttunen, M., Mitikka, S., Mykrä, H., Niemi, J.,Olin, M., Perus, J., Pilke, A., Rask, M., Ruuskanen, A., Vehanen, T. ja Westberg V. 2009.OSA I.Vertailuolot ja luokan määrittäminen. In: Vuori, K. M., Mitikka, S. ja Vuoristo, H. (Eds). Pintavesien ekologisen tilan luokittelu. Ympäristöhallinnon ohjeita 3. Suomen ympäristökeskus, Helsinki, $123 \mathrm{~s}$

Wang, R. Z., Huang, D. L., Liu, Y. G., Zhang, C., Lai, C., Wang, X., Zeng, G. M., Zhang, Q., Gong, X. M., \& Xu, P. (2020). Synergistic removal of copper and tetracycline from aqueous solution by steam-activated bambooderived biochar. Journal of Hazardous Materials, 384, 121470. https://doi.org/10.1016/j.jhazmat.2019.121470

Zhang, C., Zhang, N., Xiao, Z., Li, Z., \& Zhang, D. (2018). Characterization of biochars derived from different materials and their effects on microbial dechlorination of pentachlorophenol in a consortium. RSC Advances, 9, 917923. https://doi.org/10.1039/C8RA09410A

Zhao, J. J. et al. (2019) Comparison of biochars derived from different types of feedstock and their potential for heavy metal removal in multiple-metal solutions. Scientific Reports, 9(1). https://doi.org/10.1038/ s41598-019-46234-4

Zhou, Y., Qin, S., Verma, S., Sar, T., Sarsaiya, S., Ravindran, B., Liu, T., Sindhu, R., Patel, A. K., Binod, P., Varjani, S., Rani Singhnia, R., Zhang, Z., \& Awasthi, M. K. (2021). Production and beneficial impact of biochar for environmental application: A comprehensive review. Bioresource Technology, 337, 125451. https://doi.org/10.1016/j.biort ech.2021.125451

Publisher's Note Springer Nature remains neutral with regard to jurisdictional claims in published maps and institutional affiliations. 